\title{
Integrating assessment for learning in the teacher education programme at the University of Oslo
}

Corresponding author: Lisbeth M. Brevik

\author{
Affiliation: Associate Professor - Department of Teacher Education and School Research - \\ University of Oslo \\ Postal address: Postboks 1099 Blindern - 0317 OSLO \\ Telephone number: $+47-90036500$ \\ E-mail address: 1.m.brevik@ils.uio.no
}

Co-author: Marte Blikstad-Balas

Affiliation: Associate Professor- Department of Teacher Education and School Research University of Oslo

Postal address: Postboks 1099 Blindern - 0317 OSLO

Telephone number: $+47-90824582$

E-mail address: marte.blikstad-balas@ils.uio.no

Co-author: Kirsti Lyngvær Engelien

Affiliation: Head of Studies- Department of Teacher Education and School Research University of Oslo

Postal address: Postboks 1099 Blindern - 0317 OSLO

Telephone number: $+47-22844594$

E-mail address: k.l.engelien@ils.uio.no 


\begin{abstract}
This article provides an analysis of the integration of Assessment for Learning (AfL) principles in the newly revised 5-year Master of Education (ME) programme at the University of Oslo, Norway; across didactic subjects, pedagogy, and school practice. The analysis draws on lecture notes, student videos, and student exam papers among 143 student teachers; aiming to identify (a) the operationalisation of the assessment curriculum at the university campus, and in school practice, (b) how the student teachers use assessment principles as tools in their instructional designs, and (c) how they self-assess their teaching practice. Our main finding is that student teachers seem to be more concerned with assessing their students, than using self-assessment to improve their instruction. Based on the findings, we argue the importance of relating the teaching and learning activities with the assessment situations used in the teacher education programme.
\end{abstract}

Key words: assessment education; student teachers; teacher education; assessment for learning

\title{
Introduction
}

Newly educated teachers often struggle with using the knowledge from research-based teacher education programmes when facing challenges in the classroom (Cochran-Smith \& Fries, 2005). Cochran-Smith (2003) argued that the knowledge acquired during teacher education only to a small extent influences teachers' instructional practices. Teacher education must enable student teachers to use knowledge and skills in their practices, to enhance the link between theory and practice (Darling-Hammond, 2006; Hammerness, 2006, 2013; Hatlevik \& Smeby, 2015). The use of assessment principles is no exception (e.g., Newton, 2007; Stobart, 2006), and can be subsumed under a sociocultural perspective. This perspective will serve as a theoretical and methodological lens in this article.

In line with Black and Wiliam's (1998b) definition, we use 'the general term assessment to refer to all those activities undertaken by teachers - and their students in assessing themselves - that provide information to be used as feedback to modify the teaching and learning activities. Such assessment becomes formative assessment when the evidence is actually used to adapt the teaching to meet student needs' (p. 140). Several assessment researchers (e.g., Black, Harrison, Lee, Marshall, \& Wiliam, 2004; Wiliam, 2011a) have discussed the distinctions between assessment for learning (AfL) and assessment of learning (AoL) on the one hand, and between 
formative and summative assessment on the other. Although Wiliam (2011a) stated that these distinctions are different in kind, he argued that it might be more helpful to acknowledge that AfL and formative assessment are conducted to improve learning, whether or not one term or the other is used.

In this article, we use the term AfL, mainly because in the Norwegian context of this study, AfL is the preferred term in the educational context and policy documents, and is used synonymously with formative assessment (Norwegian Directorate for Education and Training [UDIR], 2011, p. 2). In the article, we elaborate on how AfL is integrated in the teacher education programme at the University of Oslo; an issue which arguably is relevant not only for Norwegian education, but concerns teacher education in general.

A crucial issue concerns how to develop assessment capacity in teachers through teacher education, as teacher education has historically neglected assessment. The question of how to educate future teachers in effectively using assessments to promote, monitor, and report on student learning is timelier than ever; in an increasingly accountability-oriented educational context, teachers are expected to provide dependable assessment. As a result, teacher education programmes across the world are expected to enable their student teachers to use assessment in ways that increase and reflect student performance (DeLuca \& Klinger, 2010).

This article responds to the call for increased research in assessment education by examining a newly revised five-year, integrated Master of Education (ME) programme at the University of Oslo, Norway (UiO). The $\mathrm{UiO}$ and the Norwegian Centre for Professional Learning in Teacher Education (ProTed) have collaborated to develop a future-oriented, knowledge-based programme that involves activating the innovative, future- and internationally-oriented teacher.

This article addresses key topics in assessment education, as it investigates how assessment principles and practices are integrated in the ME programme, how the student teachers use assessment principles in planning their own teaching at UiO's partner schools, and to what extent they use self-assessment (SA) principles to develop their practices. Such a perspective is in line with constructive alignment (CA), in which Biggs (1996) argued the importance of relating the teaching and learning activities with the assessment situations used in teacher education, (Lund \& Engelien, 2015). We will argue the importance of enabling student teachers to use assessment principles as mediating tools in the design of their teaching, while at the same time using the principles to self-assess their teaching practices. 
We investigate the following overarching research question: How and to what extent does the ME programme at UiO develop assessment capacity in student teachers? We use qualitative and quantitative data to investigate: first, how teacher educators at $\mathrm{UiO}$ teach principles of assessment; second, how student teachers use assessment principles as tools in their instructional designs at partner schools; and third, how they use assessment principles in their own assessment situations at $\mathrm{UiO}$. In the following, we describe the structure of the ME programme in general. We also discuss implications for the student teachers' professional development. In order to contextualise this study, we first review key features that characterise this programme and the literature related to educational assessment.

\section{University of Oslo: Master of Education programme}

In Norway, as in many other countries, there has been an increased focus on educational assessment over the past decade (Norwegian Directorate for Education and Training [UDIR], 2010; Tveit, 2014). Given this emphasis, the Norwegian Ministry of Education and Research (KD) requires teacher education to address assessment as a topic of study. The National Curriculum for Teacher Education (2013) states that student teachers should have knowledge about assessment and testing, and methods to enable assessment practice aligned to the core curriculum. The review by Tveit (2014) in this journal suggests that Norwegian teachers have found it challenging to implement the new assessment principles, making it all the more important to prepare new teachers for the new assessment demands in contemporary education.

The ME programme at $\mathrm{UiO}$ qualifies teachers to teach in Years 8-13 (13- to 18-year-old students $)^{1}$ and is structured in a two-term model, with a normal progression rate of 30 credits each term. ${ }^{2}$ The first term comprises the two components "instruction and learning" and "classroom management", while the second term comprises the components "differentiation" and "assessment". The assessment component is the focus for analysis in this article. In this course the students learn assessment practices in their pedagogy seminars and in their subject didactics seminars, as wells as during their supervised training at partner schools. This course design

\footnotetext{
${ }^{1}$ In Norway, students are obliged to attend primary and lower secondary education (Years 1-10), with a subsequent right to three years' upper secondary education and training (Years 11-13). The national curriculum introduced in 2006 and revised in 2013, The Knowledge Promotion (UDIR, 2006), defines students' learning outcome in the school subjects for the Years 1-13.

${ }^{2}$ The ME programme at UiO offers 48 different courses of study. The students can choose two school subjects (180 +60 credits), specializing in one by writing a master thesis. In addition, they take a total of 60 credits of professional teaching courses.
} 
involves three formal assessment situations: (a) a practice exam, (b) a research and development (R\&D) report, and (c) an exam essay where the student is required to deliberate a topic from the field of assessment and/or differentiated instruction. In following the principles of CA (Biggs, 1996), these exams are integrated, the student needs to build upon pedagogy and subject didactics theory, as well as experiences from their teaching practice. Together, the three formal assessment situations have a licencing purpose (Newton, 2007).

The content of the assessment component meets the requirements in the Norwegian Education Act (KD, 2006, 2013), which regulates assessment for students in primary and secondary schools. Specifically, the assessment component aims to provide student teachers with (a) knowledge about assessment theory, assessment practices and challenges in the disciplines, and the links between feedback, assessment, and learning; (b) skills that enable them to assess and document their students' learning and development, and provide feedback that promotes learning in the disciplines; and (c) competence to develop and discuss their professionalism. Based on these aims, the assessment component comprises open lectures across scientific subjects, workshops in subject domains, as well as didactics and pedagogy and seminars. As discussed in the next section, little is known about the kind of content and structure that are useful in developing assessment capacity in student teachers.

\section{What we know about assessment education}

As several researchers have pointed out, assessment is integral to effective instruction (e.g. Black \& Wiliam, 1998a, 1998b, 2009; Wiliam, 2010; 2011), and teachers are increasingly expected to use assessments to form valid judgements about student learning and for the improvement of instruction (Brevik, 2015; Brevik \& Blikstad-Balas, 2014; DeLuca, Chavez, \& Cao, 2013; DeLuca \& Klinger, 2010; Mausethagen \& Mølstad, 2015; Stobart, 2006; Tiknaz \& Sutton, 2006; Tveit, 2014).

This emphasis on formative assessment raises the question of what role teacher education plays in preparing teachers to meet such demands. Due to the limited number of studies investigating how assessment is taught in teacher education, the review is not extensive. While the general interest in assessment is high, not many teacher education programmes offer formalised assessment education (DeLuca \& Klinger, 2010; Dempster, 1992; Stiggins, 2004).

There seems to be consensus that explicit assessment courses have the potential to positively impact student teachers' understandings of assessment (DeLuca et al., 2013; DeLuca \& 
Klinger, 2010; Graham, 2005). In a study about assessment development in a teacher education programme in Canada, DeLuca and Klinger (2010) identified the participating student teachers' perceived confidence levels in assessment practice, theory, and philosophy. The results of this research demonstrate a serious challenge related to the lack of mandatory assessment courses in teacher education. In the absence of such courses, the student teachers in this study by DeLuca and Klinger (2010) obtained their confidence in assessment through practicum experience provided by teachers who most likely also lacked assessment education. This study also identified positive effects of providing student teachers with explicit assessment instruction, and 'a real benefit of direct assessment instruction in preservice, on-campus, teacher education programs' (DeLuca \& Klinger, 2010, p. 434).

It has been problematised that assessment is too often summative, implying that assessment tends to report back and summarise what has been learned, rather than being formative and in support and guidance of ongoing learning and development (e.g., Stobart, 2006; Tiknaz \& Sutton, 2006), which makes it important to investigate student teachers' use of assessment principles in their instructional designs and to identify the assessment practices they meet in their teacher education. For example, Volante and Fazio (2007) found that the student teachers in their study were primarily concerned with summative assessment such as tests and final grades. In a later study, DeLuca and colleagues' (2013) likewise found that student teachers' conception of assessment was based solely on summative testing. They discovered, however, that these student teachers expanded their conception of assessment to one that recognised multiple forms of assessment, after taking only a one-term measurement course.

The studies by Volante and Fazio (2007) and DeLuca and colleagues (2013) both suggest that teacher education may have a critical role to play in providing student teachers with deep understandings of assessment. Nicol, Thomson, and Breslin (2014, p. 102) conclude their study about assessment and student peer-review in higher education by highlighting how "the capacity to produce quality feedback is a fundamental graduate skill, and, as such, it should receive much greater attention in higher education curricula”. As argued by DeLuca and Klinger (2010), 'emphasis needs to be placed on enabling teachers to maximise the learning potential of assessment while also monitoring student progress' (p. 420). The estimate that teachers spend between $30 \%$ to $50 \%$ of their professional time engaged in assessment activities (Stiggins, 2004) further underscores the need to practice formative assessment. In order for students to be able to perform formative assessment and develop their repertoire of formative assessment practices, we 
believe it to be crucial for student teachers to provide feedback to their students in a way that not only evaluates finished activities, but also monitors, guides, and motivates student work while the students consider the process to be ongoing. The reviewed literature suggests that training teachers in assessment is crucial. In line with this suggested need for more assessment training and more focus on the formative aspects of assessment, the present study explores how student teachers are trained in assessment. Further, we will analyse and discuss the implementation of assessment education in the ME programme at UiO. In the following, we discuss how our study is framed by a Vygotskian approach.

\section{A Vygotskian approach to assessment education}

This study is based on the view that the use of AfL principles takes place within a sociocultural environment at the university and at the practice schools. This framing contributes to seeing assessment as a tool which is also a social construction (Afflerbach \& Cho, 2011). In line with Edwards (in press), we argue that conceptualising learning for student teachers as the increasingly informed use of assessment as a tool, has implications for their development:

Vygotsky explained the process by explaining learning as both internalisation and externalisation: we take in new ideas and use them as tools as we take forward our intentions. Internalisation and externalisation are key to the dialectic, our minds and behaviours are shaped as we take part in practices, but we can also shape the practices through our actions, through externalising. While Vygotsky developed these ideas to explain how children learn, they apply equally well to adults as learners and appear particularly relevant to the challenge of learning to teach while teaching, where we would expect to find evidence of student teachers' learning in their actions in the activity of teaching.

Thus, using a Vygotskian framing in this study, we argue that there is an ongoing relationship between the student teachers and the affordances and demands they encounter at the university and in school settings. We therefore employ a Vygotskian framing (Vygotsky, 1986, 1987) to examine how assessment principles are employed as tools, first by the teacher educators in teacher education at the university, and second by the student teachers at their practice schools in order to support the students as learners. Because of the particular emphasis on assessment as a pedagogic tool, we also draw on the arguments of later interpreters of Vygotsky such as Daniels (2008) and Edwards (2015, in press). 
Since the sociocultural contexts of the school and classrooms are different from the educational context of the university, the assessment principles will inevitably be transformed, adapted, and marked by the school context. In the present study, we therefore argue the importance of relating the assessment training situations used in the ME programme with the teaching and learning activities the student teachers design and experience at the practice schools (Lund \& Engelien, 2015). The Vygotskian framing therefore provides a perspective on the student teachers' use of assessment principles to develop their practices.

\section{Assessment as a pedagogic tool}

In a sociocultural approach to teaching and learning, assessment principles are tools which should mediate school assessment practices. The argument is that used as a pedagogic tool, AfL or formative assessment, has the potential to expand student teachers' knowledge of their students; while seeing them as active in their own development as learners, thereby resulting in the affordance of a pedagogy that meets the needs of students. In addition, one aspect of their active learning is that students can learn how to use SA as a tool, creating demands on themselves which help them move forward as learners, by helping them to monitor and control their own progress as students (Black, 2015; Gipps, 1999; Torrance \& Pryor, 1998).

The notion of assessment as a tool finds support in the assessment literature where, for example, Newton (2007) observed that much depends on how and why a type of assessment is used and that the same assessment technique may be used for a variety of purposes. He noted, for example, that the purpose of formative assessment is to use individual (or aggregated) results to identify student (or group) learning needs to direct subsequent teaching and learning (p. 163). He

explained that there is no summative purpose, only summative judgement, although we 'routinely characterise formative assessment by contrasting it with summative assessment and "summative" clearly does refer to a type of assessment judgement, one which involves "summing up" (the cue's in the name)' (p. 160). Along this line of argument, a summative assessment can be used for formative purposes, e.g., by using test results to identify learning needs and design instruction accordingly.

It is worth noting that assessment traditionally has focused on the effect of various teaching activities after these are over (Wiliam, 2011a), indicating a need to develop student teachers' ability to perform AfL; providing feedback to promote student learning (Black \& Wiliam, 1998a; Brevik \& Blikstad-Balas, 2014; Hattie \& Timperley, 2007; Wiliam, 2011a). A 
useful perspective on feedback is described in the Protocol for Language Arts Teaching Observation (PLATO), ${ }^{3}$ a research-based instrument used to observe the effectiveness of teachers, including feedback practices:

Feedback includes comments on the quality or nature of student work as well as suggestions for how students can improve the quality of their work. At the high end, feedback is specific and targets the skills at the heart of the activity. The feedback helps students understand the quality of their work and helps students better perform the task at hand by addressing substantive elements of the task. At the low end, feedback consists of vague comments that are not clearly anchored in student work and suggestions for improvement tend to be procedural (i.e. focused on the instructions for the activity rather than the skills or knowledge that students are applying). These comments do not help students gauge their progress and do not provide a means for students to improve. At the low end, feedback may also be confusing or misleading.

\section{The Quadrant Model as a tool in assessment education}

The Vygotskian approach to pedagogy requires us to recognise how teacher educators use assessment principles as tools, to engage student teachers with powerful cultural meanings and ways of working. This way of teaching to promote learning is emphasised in the Vygotsky-based Quadrant model of a pedagogic sequence (Edwards, 2015). The model emphasises how learners are first introduced to new concepts, or ways of working, and participate in learning situations through guided instruction (quadrant 1). Then they move towards independent use, first through tightly structured tasks (quadrant 2) and later through more open tasks (quadrant 3). Finally, they display their knowledge in some form of summative assessment (quadrant 4).

Edwards (2015) explained that the sequence is frequently disrupted with recursive loops occurring. The sequence is meant to be a flexible framework, for example learners may take time in quadrants 2 and 3 to actively engage with the task demands, to both acquire and use AfL as tools, to make mistakes, get stuck and attempt an effort after meaning, and to move from quadrant 3 to 2 or 1 if additional help is needed. It is primarily in quadrants 2 and 3 that students' use of AfL as a pedagogic tool can inform the guidance the teacher educators give. There, the student teachers are able to go back and forth flexibly between the quadrants in their learning process, to use AfL as a pedagogic tool and monitor their own progress, or to be assessed formatively by the teacher educator - with these activities informing the support they need as they take themselves forward as learners. According to this analysis, student teachers do not easily move from hearing

\footnotetext{
${ }^{3} \mathrm{http}: / /$ platorubric.stanford.edu/
} 
about AfL and then using them to design their assessment practices; rather, the potential and relevance of AfL need to be explored. Edwards (2015) emphasised that formative assessment occurs throughout the process. Building on her argument, we suggest a need to include attention to the purposes of using AfL as a tool in the ME programme at UiO. In this manner, a sociocultural framing includes social, material, and contextual resources.

\section{Methods}

This study used a multiple methods design (Bazeley \& Kemp, 2012; Creswell, 2013) involving qualitative and quantitative data to identify how assessment principles are taught and assessed in the assessment component, and how student teachers use assessment principles as tools to design their teaching practices. We ask: How and to what extent does the ME programme at UiO develop assessment capacity in student teachers? In order to answer this main research question, we have specified three research questions (RQs):

- RQ1: How are assessment principles taught across lectures, workshops, and seminars?

- RQ2: How and to what extent do student teachers use assessment principles in designing their school practices?

- RQ3: How and to what extent do student teachers use SA principles to reflect on their practices?

\section{Participants, data collection, and data analysis}

The participants in this study were student teachers in the ME programme at UiO, who were in their seventh term in the autumn of 2015, and thus participated in the assessment component $(N=143)$.

We collected data from the assessment education at the university (lecture notes); assessment situations the student teachers participated in (films, praxis cards) and designed for their students at the partner schools (lesson plans, R\&D reports); and assessment situations for the student teachers (praxis cards, R\&D reports). The data analysis included five steps (Table 1). 
Table 1. Stages of analysis.

\begin{tabular}{|c|c|c|c|}
\hline Readings & Aim & Tools of analysis & Research question \\
\hline $\begin{array}{l}\text { 1st step } \\
\text { (lecture } \\
\text { notes) }\end{array}$ & $\begin{array}{l}\text { To identify assessment } \\
\text { principles referred to in the } \\
\text { notes. }\end{array}$ & \multirow{3}{*}{$\begin{array}{l}\text { First, we identified the } \\
\text { following concepts in the } \\
\text { data: assessment for learning } \\
\text { (AfL), assessment of learning } \\
\text { (AoL), formative and/or } \\
\text { summative assessment, aims, } \\
\text { criteria, feedback, feed } \\
\text { forward, SA, exams, tests. }\end{array}$} & \multirow{3}{*}{$\begin{array}{l}\text { RQ1: How are } \\
\text { assessment principles } \\
\text { taught across } \\
\text { lectures, workshops, } \\
\text { and seminars? }\end{array}$} \\
\hline $\begin{array}{l}\text { 2nd step } \\
\text { (film) }\end{array}$ & $\begin{array}{l}\text { To identify teacher } \\
\text { educators' and student } \\
\text { teachers' perception of } \\
\text { video-based AfL. }\end{array}$ & & \\
\hline $\begin{array}{l}\text { 3rd step } \\
\text { (praxis } \\
\text { card) }\end{array}$ & $\begin{array}{l}\text { To identify student } \\
\text { teachers' participation in } \\
\text { assessment practices at the } \\
\text { practice schools. }\end{array}$ & & \\
\hline $\begin{array}{l}\text { 4th step } \\
\text { (lesson } \\
\text { plans) }\end{array}$ & $\begin{array}{l}\text { To identify how student } \\
\text { teachers designed } \\
\text { assessment situations for } \\
\text { their students, and their } \\
\text { SA of their own } \\
\text { instructional designs. }\end{array}$ & \multirow{2}{*}{$\begin{array}{l}\text { We identified the same } \\
\text { concepts in these data: } \\
\text { assessment for learning } \\
\text { (AfL), assessment of learning } \\
\text { (AoL), formative and/or } \\
\text { summative assessment, aims, } \\
\text { criteria, feedback, feed } \\
\text { forward, SA, exams, tests. }\end{array}$} & $\begin{array}{l}\text { RQ2: How and to } \\
\text { what extend do } \\
\text { student teachers use } \\
\text { assessment principles } \\
\text { as tools in designing } \\
\text { their school } \\
\text { practices? }\end{array}$ \\
\hline $\begin{array}{l}\text { 5th step } \\
\text { ( } R \& D \\
\text { reports) }\end{array}$ & $\begin{array}{l}\text { To identify how student } \\
\text { teachers designed research } \\
\text { on their assessment } \\
\text { practices. }\end{array}$ & & $\begin{array}{l}\text { RQ3: How and to } \\
\text { what extent do } \\
\text { student teachers use } \\
\text { SA principles to } \\
\text { reflect on their } \\
\text { practices? }\end{array}$ \\
\hline
\end{tabular}

\section{Validity, reliability, and ethics}

We took a number of steps to assure data validity and reliability (Creswell, 2013). First, we combined data from teacher educators and student teachers, as well as data from the university and the partner schools, seeking thematic convergence through triangulation (Creswell $\&$ Miller, 2000; Patton, 1999). Thus, we aimed to counter some of the challenges concerning selfreported data and the collection of texts, namely that self-reported data might reflect intentions rather than actual practice, and that texts per se provide no information on how they have been used. It should be noted that the goal of triangulation is not to 'demonstrate that different data sources or inquiry approaches yield essentially the same result' (Patton, 1999, p. 1193), but to test for such consistency. In this study, we have used sources that could not by themselves provide the 'same results' but, taken together, the lecture notes, the film, the praxis cards, the lesson plans, 
and the R\&D reports all contribute with different nuances to the same phenomenon, namely how assessment capacity is being developed in the ME programme at $\mathrm{UiO}$. We could have wished for a higher response rate than $56 \%$ to our survey asking for lesson plans, with $70 \%$ of the respondents giving their consent to our use of their documents. However, two student teachers gave answers that indicated a lack of time and plans as the reason, rather than a lack of willingness to share the content. Specifically, they stated 'I cannot find my lesson plan anymore; otherwise, you could have used it', and '[I] have no time or energy to find it. Otherwise, I would have bothered'.

As all three authors are employed at the department responsible for the ME programme, we took measures to increase the credibility of the study. First of all, one or more of the authors were present during several of the lectures in the assessment component, in order to validate whether what was emphasised in the lectures aligned with the documents (lecture notes) we use as data. The consistency observed gave us confidence that the lecture notes represent reliable data. Another validation of the lecture notes is that the teacher educators make their notes available online for the students immediately after the lectures, and it is customary to confer that the notes are consistent with the lesson. Second, we attempted to validate our analysis by member-checking (Creswell, 2013), asking the teacher educators to comment on our analysis of their lecture notes. Third, we used peer debriefing as recommended by Creswell (2013). These were qualified peers who not only provided support, but also challenged our assumptions methodologically and theoretically. The teacher educators and student teachers gave their voluntary consent to the use of all documents (Busher \& James, 2012; Ryen, 2011), and the data collection adheres to the ethical requirements of the Norwegian Social Science Data Services.

\section{Limitations}

A limitation of this study is that we have not analysed the actual lectures, workshops, or seminars where assessment was taught, nor the student teachers' teaching at the schools. Although these are important limitations, document analysis provides information about assessment principles expressed in these texts, and as described above, we validated the lecture notes by observing several of the lectures. Further, these documents provide insight into how the student teachers were enculturated into assessment practice that values formative purposes of assessment and assessment for learning practices. Moreover, although we did not observe how the student teachers conducted their lessons at the practice schools, they report extensively from 
these lessons themselves in their R\&D reports, and use detailed examples from their classroom instructions when discussing their assessment practices. Thus, we argue that our reliance on documentary analysis does take praxis into account, as several of the documents $(R \& D$ reports and Praxis cards) draw heavily on what happened in these lessons.

The potential for generalising the findings in our study is also limited. Still, we consider the study to be important due to its innovative and empirically substantiated approaches to - and the discussion of - challenges and dilemmas in assessment education.

\section{Findings}

In the data analysed, we found that both the teacher educators and the student teachers included assessment in their instructional designs, indicating that assessment principles taught at the university enabled the student teachers to use such principles as tools in their teaching designs. Three strands emerged in relation to how the ME programme at UiO developed assessment capacity in the student teachers. First, the majority of the lectures, workshops, and seminars concerned AfL, and included AfL practice. Second, the AfL practices the student teachers used in their teaching designs mainly concerned feedback practices during classroom teaching. Third, a clear difference existed between how the teacher educators taught SA principles, and how the student teachers used SA in and of their teaching. We discovered that this distinction can be explained by a lack of SA practice at the university. In the following sections, we will present the findings according to the three research questions, before discussing implications for assessment education.

\section{RQ1: How are assessment principles taught across lectures, workshops, and seminars?}

The lecture notes suggested that a variety of assessment principles and practices were taught in the assessment component. The notes clearly showed integration across the lectures, workshops, and seminars, with a gradual release of assessment responsibility from the teacher educators to the student teachers. ${ }^{4}$ This integration initially occurred as a set of terms presented in the lectures, which were subsequently made deference to in the workshops and seminars, where they were repeated and elaborated. The notes further indicated integration between assessment theory and practice, and provided definitions of and references to national guidelines and

\footnotetext{
${ }^{4}$ This description is inspired by Pearson and Gallagher's (1983) Gradual Release of Responsibility Model, which describes a process of how the responsibility for reading comprehension strategy use ideally transfers from the teacher to the student.
} 
research; international large-scale tests, assessment theory, and research; and research and theory in the subject domains.

The integration was further developed by the gradual release of assessment responsibility in four sequences, in line with Edwards' (2015) Quadrant model presented in the theory section. First, the teacher educators introduced key principles and terms as well as ways of working with assessment (quadrant 1). Second, they provided tightly structured tasks, in which the student teachers discussed and performed assessment collaboratively based on video-taped classroom situations and student work (quadrant 2). Third, they provided open tasks in which the student teachers independently assessed student work and gave feedback based on aims and criteria (quadrant 3). Finally, the teacher educators assessed the student teachers' use of assessment principles in their teaching designs and in exam tasks (quadrant 4). Below, we will present how the teacher educators orchestrated these learning sequences.

\section{Quadrant 1: Introduction of key principles and terms, and ways of working with assessment}

Assessment terms was initially introduced in the lectures, in line with Edwards's (2015) quadrant 1: (i) introduction to AfL, (ii) assessment of and for learning based on test use, (iii-iv) provision of feedback that promotes learning, (v) AfL: examples from school practice, and (vi) AoL. The first two covered the terms assessment, AfL, AoL, formative and summative assessment, aims, criteria, feedback, SA, exams, and tests, with references to assessment literature (Table 4) and examples from school practice. The next two elaborated on feedback using the PLATO criteria, including references to aims and SA. The last two lectures elaborated on all these terms and was directly linked to national guidelines (see Table 4): one from an AfL perspective, and the other from an AoL perspective. Still, while the terms were compared and contrasted, two pairs seemed to be presented as synonyms: AfL and formative assessment, and AoL and summative assessment. In the lectures, the student teachers were asked to reflect on assessment practices:

Lecture $i$ : Which assessment situations will you design in your own teaching? Lecture ii: Why is there a need for tests - or do we need them? Who needs them - the students, the teachers, the school, the parents, the politicians...? Have you experienced good AfL yourself? What characterised it?

Lecture iv: What kind of feedback promotes learning?

Lecture $v$ : What are some challenges with providing feedback? 
Asking the student teachers to discuss these questions seemed to require active participation in pairs and collectively. In the workshops and seminars, the teacher educators adapted the assessment terms and principles to subject-specific characteristics. Two examples illustrate this adaptation:

Foreign languages: In foreign languages, we assess communicative competence, facts and reflections about culture and society, written production, and oral interaction.

Religion and ethics: We recommend that the students' development of attitudes is not assessed summatively, but considered an aspect of competences assessed formatively. We do this so there is no doubt that the students' beliefs are exempt from assessment.

Notably, by adapting assessment principles to the subjects, the lecture notes indicated that, while some of the didactics seminars covered most of the terms, others focused on a few terms in depth. In this manner, the introduction of principles and terms occurred across the various contexts created for the assessment component. However, it is important to note that these practices are not quite the same, even if they are classified in the same quadrant. The findings might give the impression that all the teacher educators shared the same principles of AfL, which needs to be nuanced. On the one hand, the assessment component is rather new and the teacher education programme has strived to implement a shared view on AfL, which is suggested in the notes for lectures i-v. On the other hand, since the majority of the lecturers focused on AfL activities, while a minority focused on summative assessment principles in the workshops and seminars, different views on the matter are clearly suggested.

\section{Quadrant 2: Tightly structured assessment tasks}

The teacher educators created tightly structured assessment tasks, in line with Edwards's (2015) quadrant 2, in which the student teachers collaboratively practiced formative assessment of video-based classroom observations and student work. The student teachers were guided by the teacher educators, who presented the aims and criteria, and modelled assessment practice by showing the student teachers what to look for in videos and texts. These tightly structured tasks were provided in two lectures (iii-iv), and in two didactics seminars (mathematics, and social studies), to achieve agreement among the student teachers in terms of identifying the quality of the teachers' feedback (in the two lectures), and strengths in the student work, suggesting what to improve and how to get there (in the two seminars). In the lectures, a teacher educator trained 
them in how to use criteria to identify high- and low-quality feedback, and to use the PLATO criteria as tools in writing high-quality feedback to a student's video-based presentation:

Lecture iii: Do you think this film illustrates low- or high-quality feedback?

Lecture iv: Search for evidence of feedback in these films. In groups of four, agree on a final assessment of the observed teachers' feedback practices.

Lecture iv: Watch this oral student presentation. Use the criteria to write high-quality feedback to the student to promote learning and development.

Tightly structured tasks were also presented in two seminars, although instead of the PLATO criteria, the student teachers were given criteria from national exams alongside student answers that had already been assessed by examiners appointed by UDIR:

Mathematics: We assess written exam tasks in mathematics, years 10 and 11 . While assessing student answers, we discuss the assessment principles throughout, aiming to understand the grades/marks given by the examiners.

In these tightly structured tasks, the student teachers had opportunities to practice formative or summative assessment, as opposed to sequence 3, which focused on formative feedback practices.

\section{Quadrant 3: Open assessment tasks of student work}

The teacher educators gradually released the assessment responsibility to the student teachers in the workshops and seminars, in line with Edwards's (2015) quadrant 3. In the workshops, they assessed a written student text, and/or a video-taped student presentation. The assessment process seemed to be modelled on the tightly structured tasks in quadrant 2 , but more openly acknowledging the student teachers' views. The following tasks illustrate how this sequence moves back and forth between the collective and the individual, requiring active participation:

Workshop I (languages, humanities): In groups of four, draw up criteria for assessing oral skills. Then watch the video and use the criteria to give oral feedback on the students' presentations. Individually, write feedback to one of them. 
Workshop II (languages, humanities): Individually, use the criteria to give feedback on the student text. Discuss these in groups of four. What can you learn from each other's assessments?

In the following seminars, these practices were integrated in the disciplines, requiring the student teachers to assess oral student work (English, religion), written student work (history, Norwegian), or to discuss how to design an assessment situation to get evidence of a student's oral skills based on a case description (foreign languages). In the seminars, they were asked either to create criteria based on competence aims in their school subject (UDIR, 2006, 2013), or to use standardised criteria from exam tasks. These open tasks emphasised formative assessment practices, aiming to give quality feedback to develop student learning. Paradoxically, this emphasis on formative assessment was not reflected in the assessment of the student teachers' own work and performances at $\mathrm{UiO}$.

\section{Quadrant 4: Assessing the student teachers}

The teacher educators assessed the student teachers' use of assessment principles in designing their teaching and in exam tasks, in line with Edwards's (2015) quadrant 4. Four situations were directly linked to the assessment component (Figure 1); one voluntary assessment (video-based AfL), and three mandatory (praxis cards, lesson plans, R\&D reports).

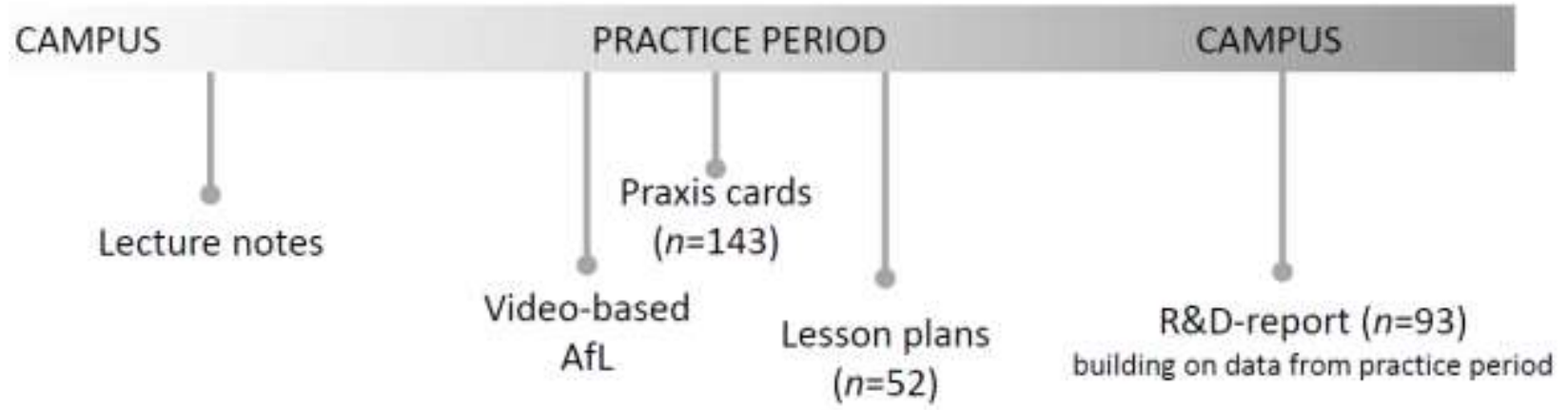

Figure 1. Lecture notes and formal assessments for the student teachers at $\mathrm{UiO}$, linked to the assessment component (seventh term). $n=$ distinct student teachers. Each of the 143 student teachers handed in their praxis card (mandatory). 52 of these student teachers submitted one lesson plan each for this study (voluntary). One R\&D report was handed in by each of the student teachers who chose assessment as their topic (mandatory). 
The video-based AfL integrated feedback from teacher educators at $\mathrm{UiO}$ and school supervisors during their practice:

Teacher educator: We want to do this project because the national guidelines require all teaching practice to be supervised, assessed, and varied. We [...] watch the videos and comment on them, bearing in mind the theory we have gone through on campus and, at the same time, commenting on things that happen in the classroom.

The assessment purpose was to develop the student teachers' ability to self-assess their teaching, and to receive feedback to improve their practices. This is an ongoing pilot project where only a group of student teachers was invited to participate $(n=35)$. The participants seemed positive towards this assessment practice, as expressed in these two quotes:

Student teacher 1: The video clips increase my professional understanding because I can go back and observe myself. [...] I submit a video, for example, to the university and receive concrete feedback. Then I can read the feedback and go back to the video. To have this combination of concrete feedback and watching the video develops my learning.

Student teacher 2: I think the videos could be useful in increasing my professional understanding, because I get to see my teaching from the students' perspective. [...] You can watch it and sort of assess your own performance. We get a lot of supervision both from supervisors and peers, but I feel it's useful to see it for myself as well, because then I may have a better understanding of the feedback I get.

These quotes not only underline the formative purpose of the assessment, but also indicate that it was used to improve their practice. The formative nature of the video-based AfL was not mirrored in the mandatory assessments, although we found some aspects of formative purposes. For example, the praxis cards documented the student teachers' participation in assessment situations at the schools, although the content of these situations was not documented. The card was signed by their supervisor, and was then part of their summative assessment at the university. Our analysis showed that all the student teachers $(\mathrm{N}=143)$ had participated in such assessment, potentially using the experience in their assessment designs in the lesson plans and the R\&D reports.

While the lesson plans showed the student teachers' design for their practice exams (45$90 \mathrm{~min}$ ), the $R \& D$ reports were written over 14 weeks to develop teacher professionalism through research-based practices, choosing whether to study assessment or differentiation. Categorising the reports, we found that $68 \%(n=93)$ concerned assessment, indicating a willingness to develop 
their assessment capacity. In these documents, the student teachers were required to integrate pedagogy and didactics theory with school practice. Teacher educators offered feedback on the research questions for the $R \& D$ reports, and while the supervisors assessed the lesson plans formatively before the exam, teacher educators assessed the plan and the exam summatively in situ.

In sum, the assessment principles and practices found in these sequences suggest that, although the main part of the assessment component concerned formative assessment, the majority of such assessments happened at the schools. At the university, they were mainly summatively judged to determine whether they should become licenced teachers. This apparent paradox will be addressed in the discussion section.

\section{RQ2: How and to what extent do student teachers use assessment principles as tools in their teaching designs?}

We have analysed two formal assessment situations directly linked to the assessment component; the student teachers' lesson plans and R\&D reports (Figure 2).



Figure 2. Assessment principles applied to the R\&D reports and the lesson plans. The percentages indicate the proportions of $\mathrm{R} \& \mathrm{D}$ assessment reports $(n=93)$ and lesson plans $(n=50)$ that included each of the assessment principles in the figure. $R \& D=$ research and development. $\mathrm{AfL}=$ assessment for learning. $\mathrm{SA}=$ self-assessment. AoL=assessment of learning. 
Figure 2 shows that only some lesson plans included summative assessment (24\%) or AoL (6\%), while more included formative assessment (46\%) and AfL (30\%), with similar patterns revealed in the R\&D reports. For the lesson plans, 44\% (n=23) included at least two of the formative assessment terms; AfL, formative assessment, feedback, or SA. Specifically, $10 \%$ of these plans $(n=5)$ included references to all four terms, another 19\% $(n=10)$ included three of these, with an additional 15\% $(n=8)$ including two of them. In comparison, 60\% $(n=30)$ included SA of their own teaching practices, which all of the student teachers were expected to do.

These findings show that the majority of these documents indicated that the student teachers planned to give their students feedback during teaching, as illustrated here:

Foreign languages: Feedback will be given to each student individually, depending on which task they work with and what I know about their mastery from previous lessons. I will give feedback when students ask for help to solve a task, or when I approach a student. I do this to offer help based on their individual needs.

English: Feedback on pronunciation in line with the principles of flow and communication, rather than strict correctness in pronunciation and intonation.

Social studies: The students will get feedback from a peer when working together. [...] the students will get feedback from me while working individually.

The first example indicates a formative assessment purpose, while the latter two are formulated in general terms and have the potential to satisfy both summative and formative assessment: summative because they indicate intentions to provide judgements of the students' mastery at a particular point in time, and formative because the feedback might relate to their students' learning and performance to help them improve.

In a similar vein, $89 \%(n=83)$ of the $\mathrm{R} \& \mathrm{D}$ reports included at least two of the formative assessment terms; AfL, formative assessment, feedback, or SA. Specifically, 33\% of these reports $(n=31)$ included references to all four terms, another $32 \%(n=30)$ included three of these, with an additional $24 \%(n=22)$ including two of them. In comparison, only $25 \%(n=23)$ included SA of their own teaching practices, and only one report referred to AoL and summative assessment. Although our analyses indicate a willingness in pursuing assessment principles, we revealed a tendency to describe what they intended to do, without explaining how or why. This is also suggested by the low percentage linking these assessments to aims $(6 \%)$ or criteria (4\%). 


\section{RQ3: How and to what extent do student teachers use SA to reflect on their practices?}

Our findings suggest that the relevance and potential of SA might be under-communicated at the university. The lecture notes suggest that practicing SA was not a priority, although SA was mentioned in most of the lectures and workshops, and in half the seminars. This finding aligns with the student teachers' lack of SA inclusion in their lesson plans (14\%) (Figure 2), although the lesson plan template includes two rubrics explicitly requiring the student teachers' to elaborate on SA. However, in the R\&D reports, 59\% included student SA in their research questions, and $23 \%$ concerned how their own SA can influence their future instruction and professionalism. This is indeed a positive finding, as it was not an explicit objective of learning to integrate SA in their reports. Two examples illustrate this matter:

History: How can I improve my assessment practice so that the students understand what they need to work with to develop their historical consciousness?

Sociology and social anthropology: How do the students experience my formative feedback in the subject sociology and social anthropology, and how can I use their feedback to improve my future practice?

Notably, while the first example illustrates SA to develop the student teacher's instructional practice, the second expresses a double SA focus; the students' SA of how they perceived the feedback on their work, and the student teacher's SA to develop future practices. Figure 2 further shows that $60 \%$ of the student teachers also included own SA in their lesson plans; a typical example being: 'I find it difficult to assess what my students have learned: I wish to develop my ability to ask relevant questions. I also wish to improve my ability to give oral feedback that improves learning'. Given that the plans explicitly require student teachers to fill in a rubric for SA of their teaching, we find it concerning that only $60 \%$ did so, particularly since their supervisor offers feedback. The remaining $40 \%$ all had content in this rubric, but it is not actual assessment of how to improve their practice; rather, such content serves as descriptive justification for their instructional designs.

Taken together, these findings highlight both the student teachers' willingness to conduct SA practices, and an indication that SA is under-communicated and seems not to be practiced at the university. 


\section{Discussion}

The question guiding this article is: How and to what extent does the ME programme at UiO develop assessment capacity in student teachers through the assessment component? As the article has illustrated, the assessment component comprises education across open lectures, workshops in subject domains, and didactics seminars. Based on our findings, we here discuss three topics we consider essential in developing assessment capacity in student teachers; the questions of assessment integration, assessment of finished products, and the apparent lack of consistency between formative and summative assessment situations.

First, the student teachers are expected to perform assessment and be assessed at the university and during their school practice. This way of integrating assessment practices at the university and at the practice schools is an attempt to make a more coherent ME programme, providing opportunities to develop their assessment competence across a range of situations. Using assessment principles as tools in school subjects in order to increase learning is a challenge for teacher education in general, with student teachers reporting that the link between theory and practice is too vague (Darling-Hammond, Hammerness, Grossman, Frances, \& Shulman, 2005). Thus, we believe the crucial element of success in a model such as the one employed at $\mathrm{UiO}$ is the move from teaching assessment principles in the lectures, to the use of these principles in the student teachers' school subjects, in the workshops and seminars, and in schools. We argue that the value of teaching isolated assessment principles is limited at best, and that the success criteria for assessment education are whether student teachers actually choose to use the principles as tools in their own teaching and research. For this to happen, it is essential for teacher education to focus on assessment not only as a theoretical principle, but as a tool for learning in the disciplines, in line with the sociocultural view of learning (Daniels, 2008; Edwards, 2015; Vygotsky, 1986, 1987). In this regard, the findings in the present study are uplifting, as a majority of the student teachers chose to actively integrate assessment in their teaching designs, using theoretical and research-based assessment knowledge (e.g., Black \& Wiliam, 1998, 2009; Brevik \& Blikstad-Balas, 2014; Hattie \& Timperley, 2007; Stobart, 2008; Wiliam, 2010).

However, our findings also indicate that student teachers are more concerned with assessing their students, than using SA to improve their instruction. Black and Wiliam's (1998a; 1998b) definition of formative assessment underscores the use of feedback to modify teaching and learning activities. In order to use evidence from assessment activities to adapt their teaching to student needs, it is crucial that student teachers also use the opportunities provided for SA, 
particularly to use students' feedback. Our analyses of the lesson plans suggested that only $60 \%$ of the student teachers successfully identified aspects of their practices that they wanted to improve, although all of them were expected to do so. We identify this as a missed opportunity, and suggest that SA should be a key area of improvement of the current model, not least as the ability to improve one's own practice is a crucial part of being a professional teacher. Thus, while we have found that the emphasis on formative assessment at the university is used as a tool to design their R\&D reports, the lack of SA practices might be manifesting itself in the student teachers' lacking SA of their own teaching in the lesson plans.

Another issue worth discussing is the nature of the assessment the student teachers participate in at the university and in schools. While they appear to have many opportunities to assess authentic written and oral student work, our findings suggest that at the university the student teachers are mainly asked to assess finished student work, in line with Wiliam's (2011b) emphasis that assessment has traditionally focused on the effect of various teaching activities after these are over. Our findings indicate that the assessment component at $\mathrm{UiO}$ reinforces such practices by overemphasising student teachers' assessment of finished products such as exams, texts, and oral presentations. These assessments may have a formative nature, encouraging the student teachers to find ways of improving the student work, and discuss how feedback should be given to the students, but in order to become teachers who practice dependable AfL, they should also be provided with opportunities to provide assessment before the students consider their own work finished.

Student teachers should practice how to give feedback to students in different stages of their work, such as during planning and drafting, or in the middle of an activity. Needless to say, a student struggling with deciding how to write, for instance, a science report requires a different kind of feedback than a student who is finishing the report. If student teachers are expected to provide quality feedback at an early stage of students' work and during classroom activities, it is crucial that they encounter such opportunities in their teacher education as well. While our analyses indicate that the student teachers are indeed concerned with providing spontaneous quality feedback at the partner schools (Grossman, Loeb, Cohen, \& Wycoff, 2013), they need to encounter more such situations at the university as well.

Our final topic of discussion concerns the division of responsibility in providing the student teachers with formative assessment on their own work. This is a matter of "walking the walk' instead of 'talking the talk'; while the student teachers are repeatedly taught the importance 
of formative assessment and encouraged to assess their students formatively, they experience several summative judgements at the university, but only the voluntary video-based AfL offers formative assessment from the teacher educators. As our findings illustrate, those who participated in this project valued the experience not only as a way to enhance their own learning during practice, but also as a way to experience first-hand the value of formative assessment. We suggest that this video project be made mandator ${ }^{5}$, to integrate formative assessment also at the university. A potential problem in placing the majority of the student teachers' experience in receiving formative assessment at the schools is the very same issue discussed by DeLuca and Klinger (2010), namely that they end up obtaining their confidence in assessment from supervisors who most likely lack explicit assessment education. The recommended increased focus on SA could also be a way to meet this challenge, as SA at UiO could provide important formative assessment experiences.

\section{Conclusion}

This study highlights the importance of including assessment training in teacher education programmes by using assessment principles as tools in situations where the student teachers are assessed themselves. Introducing, modelling, and ensuring assessment principles are used by the student teachers is the teacher educators' responsibility, just as introducing, modelling, and ensuring assessment principles are used by their students is a teacher's responsibility. Focusing on the design of assessment situations in which student teachers can transfer, use, and perform assessment based on their competence leads to a focus on mastery instead of lack of mastery. This in turn measures more than knowledge and skills, and the assessment principles will ideally be transferable from the university to school practice.

We therefore argue that competence in using assessment principles is an important aspect of teacher education. The idea is that, if we can learn more about how assessment education contributes to this relationship, we can help student teachers develop and practice more dependable assessment to respond to their learning needs. It also seems that enabling student teachers to practice formal assessment at the university before designing, participating in, and conducting AfL could help develop their assessment capacity, in terms of experiencing

\footnotetext{
${ }^{5}$ The potential ethical issues that might be associated with videoing all student teachers will have to be addressed by the Norwegian Centre for Research Data (NSD).
} 
assessment on their own performances and exams during as part of their teacher education. It will be interesting to follow future research in this area, and we hope to contribute to this avenue of research.

\section{Acknowledgements}

The authors would like to thank the editors of this special issue of Assessment in Education: Principles, policy \& practice, and the two anonymous reviewers for their invaluable comments on an earlier draft of this article. We would also like to thank The Centre for Professional learning in Teacher education (ProTed) at the University of Oslo, for supporting this study.

\section{References}

Afflerbach, P., \& Cho, B. Y. (2011). The classroom assessment of reading. In M. L. Kamil, P. D. Pearson, E. B. Moje, \& P. Afflerbach (Eds.), Handbook of reading research (Vol. IV, pp. 487-518). London and New York: Routledge.

Bazeley, P., \& Kemp, L. (2012). Mosaics, triangles, and DNA metaphors for integrated analysis in mixed methods research. Journal of Mixed Methods Research, 6(1), 55-72.

Biggs, J. (1996). Enhancing teaching through constructive alignment. Higher Education, 32(3), 347-364.

Black, P. (2015). Formative assessment - an optimistic but incomplete vision. Assessment in Education: Principles, Policy \& Practice, 22(1), 161-177. DOI: http://dx.doi.org/10.1080/0969594X.2014.999643

Black, P., Harrison, C., Lee, C., Marshall, B., \& Wiliam, D. (2004). Working inside the black box: Assessment for learning in the classroom. Phi Delta Kappan, 86(1), 8-21.

Black, P., \& Wiliam, D. (1998a). Assessment and classroom learning. Assessment in Education, 5(1), 7-77.

Black, P., \& Wiliam, D. (1998b). Inside the black box: Raising the standards through classroom assessment. Phi Delta Kappan, 80(2), 139-148.

Black, P., \& Wiliam, D. (2009). Developing the theory of formative assessment. Educational Assessment, Evaluation and Accountability, 21(1), 5-31. 
Boud, D. \& Soler, R. (2016) Sustainable assessment revisited, Assessment \& Evaluation in Higher Education, 41(3), 400-413, DOI: http://10.1080/02602938.2015.1018133

Brevik, L. M. (2015). Strategies and shoes: Can we ever have enough? Teaching and using reading comprehension strategies in general and vocational programmes. Scandinavian Journal of Educational Research. DOI: http://dx.doi.org/10.1080/00313831.2015.1075310

Brevik, L. M. \& Blikstad-Balas, M. (2014). "Blir dette vurdert, lærer?" Om vurdering for læring i klasserommet [Will this be assessed, teacher? On assessment for learning in the classroom], In E. Elstad, \& K. Helstad (Eds.), Profesjonsutvikling i skolen (pp. 191206). Oslo: Universitetsforlaget

Busher, H., \& James, N. (2012). The ethical framework of research practice. In A. Briggs, M. Coleman, \& M. Morrison (Eds.), Research methods in educational leadership \& management (3rd ed.). London: SAGE Publications, Ltd.

Cochran-Smith, M. (2003). Assessing assessment in teacher education. Journal of Teacher Education, 54(3), 187-193.

Cochran-Smith, M., \& Fries, K. (2005). Researching teacher education in changing times:

Politics and paradigms. In M. Cochran-Smith \& K. M. Zeichner (Eds.), Studying teacher education: The report of the AERA Panel on research and teacher education (pp. 69-110). Mahwah, NJ: Lawrence Erlbaum Associates, Inc.

Creswell, J.W. (2013). Qualitative inquiry \& research design. Choosing among five approaches (3rd ed.). Los Angeles: SAGE Publications Inc.

Creswell, J. W., \& Miller, D. L. (2000). Determining validity in qualitative inquiry. Theory into Practice, 39(3), 124-130.

Daniels, H. (2008). Vygotsky and research. London and NY: Routledge.

Darling-Hammond, L. (2006). Assessing teacher education. Journal of Teacher Education, 57(2), $120-138$.

Darling-Hammond, L., Hammerness, K., Grossman, P., Frances, R., \& Shulman, L. (2005). The Design of Teacher Education Programs. In Darling-Hammond, L., Bransford, J., LePage, P., Hammerness, K., \& Duffy, H. (Eds.). (2005). Preparing teachers for a changing world. What teachers should learn and be able to do (pp. 390-441. San Francisco: Jossey-Bass. DeLuca, C., Chavez, T., \& Cao, C. (2013). Pedagogies for preservice assessment education: Supporting teacher candidates' assessment literacy development. The Teacher Educator, 48(2), 128-142. 
DeLuca, C., \& Klinger, D. A. (2010). Assessment literacy development: Identifying gaps in teacher candidates' learning. Assessment in Education: Principles, Policy \& Practice, 17(4), 419-438.

Dempster, F. N. (1992). Using tests to promote learning: A neglected classroom resource. Journal of Research and Development in Education, 25(4), 213-217.

Edwards, A. (in press). The Dialectic of Person and Practice: how cultural-historical accounts of agency can inform teacher education. In J. Clandinin \& J. Husu (Eds.) International Handbook on Research on Teacher Education, Thousand Oaks, CA: Sage.

Edwards, A. (2015). Designing tasks which engage learners with knowledge. In I. Thompson (Ed), Designing tasks in secondary education. Enhancing subject understanding and student engagement (pp. 13-27). UK and USA: Routledge.

Gipps, C. (1999). Socio-cultural aspects of assessment. Review of Research in Education, 24(1), 355-392.

Graham, P. (2005). Classroom-based assessment: Changing knowledge and practice through preservice teacher education. Teaching and Teacher Education, 21(6), 607-621.

Grossman, P., Loeb, S., Cohen, J., \& Wycoff, J. (2013). Measure for measure: The relationship between measures of instructional practice in middle school English language arts and teachers' value-added scores. American Journal of Education, 119(3), 445-470.

Hammerness, K. (2006). From coherence in theory to coherence in practice. The Teachers College Record, 108(7), 1241-1265.

Hammerness, K. (2013). Examining features of teacher education in Norway. Scandinavian Journal of Educational Research, 57(4), 400-419.

Hatlevik, I. K. R., \& Smeby, J. C. (2015). Programme coherence and epistemological beliefs. Nordic Psychology, 67(2), 136-153.

Hattie, J. (2009). Visible learning; A synthesis of over 800 meta-analyses relating to achievement. London: Routledge.

Hattie, J., \& Timperley, H. (2007). The power of feedback. Review of Educational Research, 77(1), 81-112.

Lund, A. (2008). Assessment made visible: Individual and collective practices. Mind, Culture, and Activity, 15(1), 32-51.

Lund, A. \& Engelien, K. L. (2015). Oppgaver og vurdering i digitale omgivelser [Tasks and assessment in digital environments]. In U. E. Rindal, A. Lund, \& R. E. 
Jakhelln (Eds.), Veier til fremragende larerutdanning (pp. 136 - 148). Oslo:

Universitetsforlaget.

Mausethagen, S., \& Mølstad, C. E. (2015). Shifts in curriculum control: Contesting ideas of teacher autonomy. Nordic Journal of Studies in Educational Policy, 1(2).

Newton, P. E. (2007). Clarifying the purposes of educational assessment. Assessment in Education, 14(2), 149-170.

Norwegian Directorate for Education and Training [UDIR]. (2010). Underveisvurdering i fag. Lare mer og bedre - hvilken betydning har laereres vurderingspraksis? [Assessment for Learning in the disciplines. Learning more and better - what is the effects of teachers' assessment practice?] Oslo: Author.

Norwegian Directorate for Education and Training [UDIR]. (2011). Grunnlagsdokument. Satsingen Vurdering for Laering 2010 - 2014 [Main document. Programme Assessment for Learning 2010 - 2014]. Oslo: Author.

Norwegian Ministry of Education and Research [KD]. (2006, 2013). Lareplan for grunnskolen og videregående skole [Curriculum for elementary and secondary school]. Oslo: Author.

Norwegian Ministry of Education and Research [KD]. (2009). Individuell vurdering i grunnskolen og i vidaregåande opplæring [Individual assessment in primary and secondary school]. Forskrift til opplaringslova. Oslo: Author.

Norwegian Ministry of Education and Research [KD]. (2013). Forskrift om rammeplan for lektorutdanning for trinn 8-13 [National Curriculum for five-year teacher education programmes]. Oslo: Author.

Norwegian Ministry of Education and Research [KD]. (2015). NOU 2015:8 Fremtidens skole. Fornyelse av fag og kompetanser [Pupils' learning in the school for the future]. Oslo: Author.

Patton, M. Q. (1999). Enhancing the quality and credibility of qualitative analysis. Health Services Research, 34(5 Pt 2), 1189-1208.

Pearson, P. D., \& Gallagher, M. C. (1983). The instruction of reading comprehension. Contemporary Educational Psychology, 8, 317-344.

Ryen, A. (2011). Ethics and qualitative research. In D. Silverman (Ed.), Qualitative research (3 ${ }^{\text {rd }}$ ed., 416-438). London: SAGE Publications, Ltd.

Stiggins, R. J. (2004). Classroom assessment for student learning: Doing it right--using it well. Portland, Oregon: Assessment Training Institute. 
Stobart, G. (2006). The validity of formative assessment. Assessment in Education Principles, Policy, \& Practice, 13(3), 235-238.

Stobart, G. (2008). Introduction. In G. Stobart (Ed.), Testing times. The uses and abuses of assessment (pp. 1-11). Oxon: Routledge.

Tiknaz, Y., \& Sutton, A. (2006). Exploring the role of assessment tasks to promote formative assessment in Key Stage 3 Geography: Evidence from twelve teachers. Assessment in Education: Principles, Policy, \& Practice, 13(3), 327-343.

Torrance, H., \& Pryor, J. (1998). Investigating formative assessment: Teaching, learning and assessment in the classroom. UK: McGraw-Hill Education.

Tveit, S. (2014). Educational assessment in Norway. Assessment in Education: Principles, Policy \& Practice, 21(2), 221-237.

Volante, L., \& Fazio, X. (2007). Exploring teacher candidates' assessment literacy: Implications for teacher education reform and professional development. Canadian Journal of Education, 30(3), 749-770.

Vygotsky, L. S. (1986). Thought and language. A. Kozulin (Ed.). London: The MIT Press.

Vygotsky, L. S. (1987). The collected works of L.S. Vygotsky, Vol. 1 Problems of general psychology. R. W. Reiber \& A. S. Carton (Eds.). New York: Plenum Press.

Wiliam, D. (2010). The role of formative assessment in effective learning environments. In H. Dumont, D. Istance, \& F. Benavides (Eds.), The nature of learning: Using research to inspire practice (pp. 135-159). OECD Publishing.

Wiliam, D. (2011a). Embedded formative assessment. Bloomington, IN: Solution Tree Press.

Wiliam, D. (2011b). What is assessment for learning? Studies in Educational Evaluation, 37, 314. 